\title{
Lead Tolerance and Accumulation in White Poplar Cultivated In Vitro
}

Branislav Kovačević

University of Novi Sad,

Institute of Lowland Forestry and Environment, Novi Sad, Serbia,

E-mail: branek@uns.ac.rs

\section{Saša Orlović}

University of Novi Sad,

Institute of Lowland Forestry and Environment,

Novi Sad, Serbia

\section{Marko Kebert}

University of Novi Sad,

Institute of Lowland Forestry and Environment,

Novi Sad, Serbia

\section{Abstract}

Background and purpose: This paper analyses the lead tolerance and accumulation in white poplar genotypes in vitro, in order to optimize genotype evaluation and other procedures in their implementation in phytoremediation projects and landscaping in areas endangered by lead accumulation.

Material and Methods: The lead tolerance and accumulation of five white poplar genotypes after 35 days in vitro cultivation on media supplemented with lead was examined. The following $\mathrm{Pb}\left(\mathrm{NO}_{3}\right)_{2}$ concentrations were used: $0,10^{-6}, 10^{-5}, 10^{-4}$ and $10^{-3} \mathrm{M}$. Tolerance analysis (described by tolerance indices) was based on morphological parameters, biomass accumulation and the content of photosynthetic pigments, while lead accumulation was described by shoot lead accumulation and shoot lead content.

Results and Conclusions: The chosen lead concentrations appeared not to be lethal. Moreover, the obtained results showed that the tested lead concentrations had a positive effect on: number of formed roots, shoot moisture content and shoot height. The best differentiation among the examined genotypes was gained by the tolerance index based on the shoot height on $10^{-4} \mathrm{MPb}\left(\mathrm{NO}_{3}\right)_{2}$. The shoot lead accumulation and shoot lead content significantly increased on $10^{-4}$ and $10^{-3} \mathrm{M} \mathrm{Pb}\left(\mathrm{NO}_{3}\right)_{2}$ media. Thus, the concentration of $10^{-4} \mathrm{M} \mathrm{Pb}\left(\mathrm{NO}_{3}\right)_{2}$ is recommended for further research. Two examined genotypes of horticultural value (LCM and LBM) achieved a significantly higher lead shoot content compared to the wide spread genotype "Villafranca" (almost 200\% and 125\% higher, respectively).

Keywords: Populus alba, tissue culture, phytoextraction
Dragana Miladinović

Institute of Field and Vegetable Crops, Novi Sad, Serbia

\section{Marina Katanić}

University of Novi Sad,

Institute of Lowland Forestry and Environment, Novi Sad, Serbia

Jovana Kovinčić

University of Novi Sad, Faculty of Agriculture, Novi Sad, Serbia

\section{Abbreviations}

ACM - Aspen culture medium

BAP 6 - Benzylaminopurine

NAA $\alpha$ - Naphthalene acetic acid

$\mathrm{Pb}\left(\mathrm{NO}_{3}\right)_{2}$ - Lead nitrate

Chl - chlorophyll

AAS - Atomic Absorption Spectrophotometer

\section{INTRODUCTION}

In recent years, the ecosystem and human habitable zones have been significantly polluted by various heavy metals. Heavy metals are potentially harmful to human health, as well as to plants and other living beings in general [1].

The toxic effect of most heavy metals is caused by their bonding to SH protein groups leading to the inhibition of enzyme activity and compromising their structure. They also substitute essential elements in biomolecules causing their deficiency [2]. High concentrations of metal ions in the soil limit the assimilation of important micro- and macronutrients by plants $[3,4]$.

Lead is one of the most toxic heavy metals [5] and a major pollutant in both terrestrial and aquatic ecosystems [6]. It affects enzyme activity and inhibits electron transport during oxidative phosphorylation, stimulating the formation of free radicals and reactive oxygen species resulting in oxidative stress $[7,8]$. Lead naturally occurs in the soil but its content may be 
greatly increased by human activities [7]. River sediments also receive significant anthropogenic loads of metals from both point and nonpoint sources [9].

The research on the influence of different plant species on the contaminated soils and underground water started in the early 1980s [10-12]. The technology of using plants to remove heavy metals from the substrate is known as phytoremediation. Trees were suggested as a low-cost, sustainable and ecologically sound solution for the remediation of heavy metal-contaminated land [13], especially by phytoextraction [14].

Poplars are often used in phytoremediation due to their fast growth, adaptability, a well-developed root system that reaches underground waters, and the ability to transpire considerable amounts of water [15]. Poplars are not able to match hiperaccumulators in the heavy metal accumulation, but their main advantage is in the large biomass production [13] and a relativly high quantity of extracted metal per plant [14]. White poplars (section Leuce Duby.) in particular, are interesting for their high tolerance to arid conditions and their implementation in horticulture and landscaping, especially the genotypes with a pyramidal tree shape $[16,17]$. The in vitro culture of tree species offers a rapid instrument to produce the clonal planting stock, but it may also facilitate studies on the effects of elevated levels of heavy metals on plant performance and the selection of metal-tolerant genotypes. Developmental and molecular data obtained by Castiglione et al. [18] in the research of white poplars suggested that the in vitro model was a sensitive and reliable system to study heavy metal stress responses. This is an important fact considering the difficulties in experimenting on large, long-lived organisms. The tolerance of white poplars to heavy metals, including lead, was tested in controlled conditions, and the differences among the genotypes were found [14, 19-23].

In this research, we studied different white poplar (Populus alba L.) genotypes in vitro for their lead tolerance based on morphological parameters, biomass accumulation and photosynthetic pigments content, as well as the lead accumulation in the above-ground plant parts.

TABLE 1

Examined white poplar genotypes

\begin{tabular}{|c|c|l|}
\hline Name & Origin ${ }^{\text {a) }}$ & \multicolumn{1}{|c|}{ Description } \\
\hline Villafranca & Italy & Model genotype, straight narrow tree \\
\hline L-12 & Serbia & Experimental clone, vigorous straight tree \\
\hline L-80 & Serbia & Experimental clone, vigorous straight tree \\
\hline LBM & Serbia & Horticultural genotype, straight pyramidal tree shape \\
\hline LCM & Serbia & Horticultural genotype, straight "bolleana" variety \\
\hline
\end{tabular}

a) - All examined genotypes were selected in Institute of Lowland Forestry and Environment, Novi Sad, Serbia, except the clone "Villafranca", that was selected in Poplar Research Institute in Casale Monferrato, Italy
The aim was to evaluate and select lead tolerant and accumulating genotypes, potentially interesting for lead phytoextraction on lead contaminated soils.

\section{MATERIAL AND METHODS}

\section{Plant Material and Shoot Multiplication}

Five white poplar genotypes, considered to be interesting for the biomass production, landscaping and horticulture were used in the research (Table 1). The genotype "Villafranca" was used as a standard, regarding the fact that it is widely used in biotechnology and in vitro studies of the heavy metal effect on white poplars [14, 18]. ACM (Aspen Culture Medium), described by Ahuja [24], supplemented with $20 \mathrm{mg} / \mathrm{l}$ adenine-sulphate, $100 \mathrm{mg} / \mathrm{l}$ myoinositole, $0.5 \mathrm{mg} / \mathrm{l}$ benzylaminopurine (BAP), 0.02 $\mathrm{mg} / \mathrm{l} \alpha$-naphthaleneacetic acid (NAA), $9 \mathrm{~g} / \mathrm{l}$ of agar and $20 \mathrm{~g} / \mathrm{l}$ of sucrose, $\mathrm{pH} 5.5$, was used for the shoot multiplication. Shoots of all five tested genotypes were multiplied through the shoot tip culture. The cultures were kept at $26 \pm 2^{\circ} \mathrm{C}$ in the white fluorescent light (3500 lux) with a 16 hour photoperiod and subcultured at 4-week intervals.

\section{Lead Treatments}

For the experiment, $1.5-2.0 \mathrm{~cm}$ long shoot tips of the previously multiplied shoots were placed on the rooting medium based on ACM with added $9 \mathrm{~g} / \mathrm{l}$ of agar and $20 \mathrm{~g} / \mathrm{l}$ of sucrose, pH 5.5, and supplemented with the following concentrations of lead in the form of $\mathrm{Pb}\left(\mathrm{NO}_{3}\right)_{2}: 0$ (as a Control), $10^{-6}, 10^{-5}, 10^{-4}$ and $10^{-3} \mathrm{M}$.

The cultures were kept in the same conditions as previously described. Three jars with five plants per jar were set for each combination of the genotype $\times$ lead concentration in three repetitions. For pigment content determination, additional three jars with five shoots per jar were established per each combination of the genotype $\times$ lead concentration.

\section{Lead Tolerance Assessment}

After 35 days of cultivation, the following morphological traits were determined: the number of 
roots per shoot and the height of the shoot. The data for the number of roots was transformed by square transformation $(\sqrt{X+1})$ in order to meet the normal distribution of frequencies.

The following traits describing biomass were determined: fresh shoot mass per plant, dry shoot mass per plant and the shoot water content. For the dry biomass calculation fifteen rootless shoots tips were dried at $100^{\circ} \mathrm{C}$ for $24 \mathrm{~h}$ and weighted. The fresh and dry biomass production was calculated as a difference between the fresh and dry biomass at the beginning and at the end of the experiment. The concentration of chloroplast pigments: chlorophyll a (Chl a), chlorophyll b (Chl b) and total carotenoids, was determined spectrophotometrically [25]. The $\mathrm{Chl} \mathrm{a}+\mathrm{b}$ and chlorophyll $\mathrm{a} / \mathrm{b}$ ratios were calculated.

The toxicity of the applied lead concentration and differences in lead tolerance among the examined genotypes were evaluated by tolerance indices. The tolerance index (TI) was calculated according to [26], as a ratio between the value of a parameter on the medium with a particular lead concentration $\left(\mathrm{X}_{\mathrm{c}(\mathrm{Pb})}\right)$ and the value obtained on the Control $\left(\mathrm{X}_{\text {control }}\right)$ :

$$
T I=\frac{X_{c(P b)}}{X_{\text {Control }}}
$$

Tolerance indices were calculated for morphological traits, dry shoot biomass production traits and photosynthetic pigments content parameters.

\section{Lead Accumulation Assessment}

In order to determine lead accumulation i.e. the lead concentration in the dry biomass $(\mathrm{mg} / \mathrm{kg}$ ), samples were mineralized by wet ashing in the microwave digester and $65 \% \mathrm{HNO}_{3}$ and $30 \% \mathrm{H}_{2} \mathrm{O}_{2}(5: 1 \mathrm{v} / \mathrm{v})$. The lead content in a sample was detemined by the atomic absorption sectrometry (AA 240FS Fast Sequental Atomic Absorption Spectrometer, Varian, Australia). For the evaluation of the lead shoot accumulation of examined genotypes, shoot lead accumulation ( $\mathrm{Pb}^{2+}$ content per shoot dry mass) and shoot lead content (calculated as the product of mean dry biomass of shoot per plantlet and mean $\mathrm{Pb}^{2+}$ content per shoot dry mass) were determined.

\section{Statistical Analysis}

The whole experiment was designed as completely randomized. The obtained data was analyzed by ANOVA and ANCOVA, as well as the LSD test with STATISTICA 10 statistical program [27].

\section{RESULTS}

\section{Morphological Characters}

No considerable chlorosis, necrosis or decay of shoot tissue was observed, and the rooting was nearly $100 \%$ on all examined media. Only on the medium with $10^{-3} \mathrm{M} \mathrm{c}\left(\mathrm{Pb}\left(\mathrm{NO}_{3}\right)_{2}\right)$ a partial darkening of roots was noticed. According to the results of ANOVA, differences among the genotypes had significant effect on the variation of the examined morphological traits (Table

TABLE 2

Results of F-test for examined characters in white poplar genotypes on examined media

\begin{tabular}{|c|c|c|c|}
\hline \multirow{2}{*}{ Examined characters } & \multicolumn{3}{|c|}{ Source of variation } \\
\hline & Genotype (A) & $\mathrm{c}\left(\mathrm{Pb}\left(\mathrm{NO}_{3}\right)_{2}\right)(\mathrm{B})$ & Interaction $\mathrm{A} \times \mathrm{B}$ \\
\hline \multicolumn{4}{|c|}{ Morphological characters } \\
\hline Number of roots & $34.58^{* * \text { a) }}$ & $3.55^{* *}$ & 0.77 \\
\hline The length of the longest root $(\mathrm{mm})$ & $28.42^{*}$ & 1.75 & 0.88 \\
\hline Shoot height $(\mathrm{mm})$ & $27.23 * *$ & $5.33^{* *}$ & 1.17 \\
\hline \multicolumn{4}{|c|}{ Biomass characters } \\
\hline Shoot water content (\%) & $3.816^{* *}$ & $4.883^{* *}$ & 1.203 \\
\hline Fresh shoot mass production (g/plant) & $12.761^{* *}$ & $3.089^{*}$ & 0.413 \\
\hline Dry shoot mass production (g/plant) & $4.776^{* *}$ & $3.058 * *$ & 0.361 \\
\hline \multicolumn{4}{|c|}{ Content of photosinthetic pigments } \\
\hline Chlorophyll a content $(\mathrm{mg} / \mathrm{kg})$ & $12.938 * *$ & 0.453 & 0.722 \\
\hline Chlorophyll b content $(\mathrm{mg} / \mathrm{kg})$ & $6.924 * *$ & 0.974 & 0.919 \\
\hline Chlorophyll $\mathrm{a}+\mathrm{b}$ content $(\mathrm{mg} / \mathrm{kg})$ & $9.580 * *$ & 0.597 & 0.726 \\
\hline Carotenoides content $(\mathrm{mg} / \mathrm{kg})$ & $11.581 * *$ & 0.633 & 0.781 \\
\hline Chlorophyll a/b ratio & $82.763^{* *}$ & 1.335 & $3.100 * *$ \\
\hline \multicolumn{4}{|c|}{ Shoot lead accumulation characters } \\
\hline Shoot lead accumulation $(\mathrm{mg} / \mathrm{kg})$ & 1.86 & $43.08^{* *}$ & 0.58 \\
\hline Shoot lead content (mM Pbºlplant) & $2.94^{*}$ & $33.13^{* *}$ & 0.96 \\
\hline
\end{tabular}

a) Labels for F-test: * - significant at the level $\alpha=0.05$; ** - significant at the level $\alpha=0.01$ 
2). The effect of lead concentration was significant for a number of roots and shoot height, while interaction genotype $\times$ lead concentration had no significant influence on any of the examined morphological traits. The controlled sources of variation had the lowest influence on the variation of the length of the longest root.

All examined lead concentrations significantly stimulated root formation. The most stimulative effect on the number of roots was observed in L-12 in the medium with $10^{-6} \mathrm{M} \mathrm{c}\left(\mathrm{Pb}\left(\mathrm{NO}_{3}\right)_{2}\right)$ and in $\mathrm{L}-80$ in media with $10^{-4} \mathrm{M}$ and $10^{-6} \mathrm{M} \mathrm{c}\left(\mathrm{Pb}\left(\mathrm{NO}_{3}\right)_{2}\right)$ (Table 3). The differences in tolerance indices for this trait and for the length of the longest root were mostly not significant, therefore indices based on these two traits were excluded from further tolerance evaluation (data not shown).

Shoot height showed a similar positive reaction to lead treatment as the number of roots (data not shown). The tolerance indices for this trait were mostly higher than 1 , indicating a high tolerance of the examined clones to the presence of lead (Table 4). Tolerance indices for this trait differed significantly among the examined genotypes in all tested lead concentrations, with best results for genotypes $\mathrm{L}-12$ and $\mathrm{L}-80$.

\section{Biomass Characters}

All biomass traits were significantly affected by both genotype and $\mathrm{Pb}$ concentration in the nutrient medium (Table 2).
Generally, tolerance indices revealed the highest dry shoot mass production was achieved on the medium with $10^{-6} \mathrm{M} \mathrm{Pb}\left(\mathrm{NO}_{3}\right)_{2}$, followed by decrease on media with $10^{-5} \mathrm{M} \mathrm{Pb}\left(\mathrm{NO}_{3}\right)_{2}$ and $10^{-4} \mathrm{M} \mathrm{Pb}\left(\mathrm{NO}_{3}\right)_{2}$ and not significant increase in medium with $10^{-3} \mathrm{M} \mathrm{Pb}\left(\mathrm{NO}_{3}\right)_{2}$ (Table 5). Similar relations among treatments were found for fresh shoot mass production, but plants on all media supplemented with lead had a significantly higher shoot water content than in the Control (data not shown).

According to the tolerance index based on dry shoot mass production, the differences among the genotypes were only significant on the medium with $10^{-6} \mathrm{M} \mathrm{Pb}\left(\mathrm{NO}_{3}\right)_{2}$. The differences in tolerance index were rather low among the examined genotypes. The highest tolerance index for dry shoot mass production was observed in genotype L-12 (Table 5). The data for fresh shoot mass revealed similar relations among the genotypes (data not shown).

\section{Influence of Rooting and Shoot Height on Biomass Traits}

The analysis of the covariance showed that the number of roots had a significant influence on the shoots' height and water content (Table 6). The influence of the number of roots on dry shoot mass production was not significant, but a significant influence of the tolerance index for shoot height on the variation of the tolerance indices of dry shoot mass production was observed.

\section{TABLE 3}

Number of roots in white poplar on examined lead concentration in medium (LSD test)

\begin{tabular}{|c|c|c|c|c|c|c|}
\hline $\mathrm{c}\left(\mathrm{Pb}\left(\mathrm{NO}_{3}\right)_{2}\right)(\mathrm{M})$ & Villafranca & L12 & L80 & LBM & $\begin{array}{c}\text { Mean value } \\
\text { by medium }\end{array}$ \\
\hline 0 & $\left.4.31^{\text {abcdef } *}\right)$ & $3.61^{\text {cdef }}$ & $3.16^{\mathrm{fg}}$ & $3.37^{\text {ef }}$ & $1.67^{\mathrm{h}}$ & $3.18^{\mathrm{b}}$ \\
\hline $10^{-6}$ & $4.54^{\text {abcde }}$ & $5.26^{\mathrm{a}}$ & $4.51^{\text {abcde }}$ & $4.32^{\text {abcdef }}$ & $2.05^{\mathrm{h}}$ & $4.07^{\mathrm{a}}$ \\
\hline $10^{-5}$ & $4.76^{\mathrm{abc}}$ & $4.97^{\mathrm{ab}}$ & $3.60^{\text {cdef }}$ & $4.33^{\text {abcdef }}$ & $2.28^{\mathrm{gh}}$ & $3.94^{\mathrm{a}}$ \\
\hline $10^{-4}$ & $4.59^{\mathrm{abcd}}$ & $4.26^{\text {abcdef }}$ & $4.62^{\text {abcd }}$ & $3.45^{\text {def }}$ & $2.17^{\mathrm{gh}}$ & $3.77^{\mathrm{a}}$ \\
\hline $10^{-3}$ & $5.20^{\mathrm{a}}$ & $4.56^{\text {abcde }}$ & $3.86^{\text {bcdef }}$ & $3.52^{\text {def }}$ & $2.26^{\text {gh }}$ & $3.83^{\mathrm{a}}$ \\
\hline Mean value by genotype & $4.73^{\mathrm{a}}$ & $4.62^{\mathrm{a}}$ & $4.00^{\mathrm{b}}$ & $3.90^{\mathrm{b}}$ & $2.13^{\mathrm{c}}$ & \\
\hline
\end{tabular}

*) The differences among values marked with the same letter are not significant at the level $\alpha=0.05$

\section{TABLE 4}

Tolerance index for shoot height of white poplar on examined lead concentration in medium (LSD test)

\begin{tabular}{|c|l|l|l|l|l|c|}
\hline $\mathrm{c}\left(\mathrm{Pb}\left(\mathrm{NO}_{3}\right)_{2}\right)(\mathrm{M})$ & Villafranca & $\mathrm{L}-12$ & L-80 & LBM & $\begin{array}{c}\text { Mean value } \\
\text { by medium }\end{array}$ \\
\hline $10^{-6}$ & $1.028^{\mathrm{fgh}}$ & $1.350^{\mathrm{a}}$ & $1.281^{\mathrm{abc}}$ & $1.259^{\mathrm{abcd}}$ & $1.131^{\mathrm{bcdefgh}}$ & $1.210^{\mathrm{a}}$ \\
\hline $10^{-5}$ & $0.963^{\mathrm{h}}$ & $1.320^{\mathrm{ab}}$ & $1.227^{\mathrm{abcdef}}$ & $1.228^{\text {abcdef }}$ & $1.064^{\text {defgh }}$ & $1.160^{\mathrm{a}}$ \\
\hline $10^{-4}$ & $0.984^{\mathrm{gh}}$ & $1.240^{\mathrm{abcde}}$ & $1.328^{\mathrm{ab}}$ & $1.071^{\text {defgh }}$ & $1.042^{\text {efgh }}$ & $1.133^{\mathrm{a}}$ \\
\hline $10^{-3}$ & $1.063^{\text {defgh }}$ & $1.319^{\mathrm{ab}}$ & $1.167^{\mathrm{abcdefg}}$ & $1.025^{\mathrm{gh}}$ & $1.099^{\text {cdefgh }}$ & $1.135^{\mathrm{a}}$ \\
\hline Mean value by genotype & $1.010^{\mathrm{c}}$ & $1.307^{\mathrm{a}}$ & $1.251^{\mathrm{a}}$ & $1.146^{\mathrm{b}}$ & $1.084^{\mathrm{bc}}$ & \\
\hline
\end{tabular}

*) The differences among values marked with the same letter are not significant at the level $\alpha=0.05$ 


\section{TABLE 5}

Tolerance index for dry shoot mass production of white poplar on media with examined lead concentrations (LSD - test)

\begin{tabular}{|c|c|c|c|c|c|c|}
\hline$c\left(\mathrm{~Pb}\left(\mathrm{NO}_{3}\right)_{2}\right)(\mathrm{M})$ & Villafranca & L-12 & L-80 & LBM & $\begin{array}{c}\text { Mean value } \\
\text { by medium }\end{array}$ \\
\hline $10^{-6}$ & $0.801^{\mathrm{bc}}$ & $1.328^{\mathrm{a}}$ & $0.887^{\mathrm{abc}}$ & $1.068^{\mathrm{abc}}$ & $1.175^{\mathrm{ab}}$ & $1.052^{\mathrm{a}}$ \\
\hline $10^{-5}$ & $0.666^{\mathrm{c}}$ & $0.739^{\mathrm{bc}}$ & $0.646^{\mathrm{c}}$ & $0.741^{\mathrm{bc}}$ & $0.943^{\mathrm{abc}}$ & $0.747^{\mathrm{b}}$ \\
\hline $10^{-4}$ & $0.681^{\mathrm{c}}$ & $0.757^{\mathrm{bc}}$ & $0.747^{\mathrm{bc}}$ & $0.878^{\mathrm{abc}}$ & $0.916^{\mathrm{abc}}$ & $0.796^{\mathrm{b}}$ \\
\hline $10^{-3}$ & $0.927^{\mathrm{abc}}$ & $0.946^{\mathrm{abc}}$ & $0.818^{\mathrm{bc}}$ & $0.960^{\mathrm{abc}}$ & $0.910^{\mathrm{abc}}$ & $0.912^{\mathrm{ab}}$ \\
\hline Mean value by genotype & $0.769^{\mathrm{a}}$ & $0.942^{\mathrm{a}}$ & $0.775^{\mathrm{a}}$ & $0.912^{\mathrm{a}}$ & $0.986^{\mathrm{a}}$ & \\
\hline
\end{tabular}

*) The differences among values marked with the same letter are not significant at the level $\alpha=0.05$

The effect of the differences among the genotypes on this trait was not significant.

\section{Photosynthetic Pigments Content}

According to the ANOVA results, genotype had a significant effect on the variation of the content of the examined photosynthetic pigments, as well as $\mathrm{Chl} \mathrm{a} / \mathrm{b}$ ratio, while the interaction genotype $\times$ lead concentration had a significant effect only on $\mathrm{Chl} \mathrm{a/b}$ ratio (Table 2 ).
The content of all of the studied pigments, the base tolerance index, was not significantly affected by the controlled sources of variation. However, the tolerance index based on $\mathrm{Chl}$ a/b was also under a significant influence of the genotype and genotype $\times$ lead concentration (data not shown). The highest tolerance indices were observed in "Villafranca" and the lowest in LCM and L-12. The tolerance index gradually decreased with the increase of lead concentration, suggesting the increase of the chlorophyll b share (Table 7).

\section{TABLE 6}

F-test from the analysis of covariance for some characters of interest for lead tolerance in white poplar genotypes

\begin{tabular}{|c|c|c|c|c|c|}
\hline \multirow{2}{*}{\begin{tabular}{c}
\multirow{2}{*}{$\begin{array}{c}\text { Source } \\
\text { of } \\
\text { variation }\end{array}$} \\
\cline { 2 - 6 }
\end{tabular}} & \multicolumn{4}{|c|}{ Number of roots } & \multicolumn{2}{c|}{$\begin{array}{c}\text { Tolerance index } \\
\text { for shoot height }\end{array}$} \\
\cline { 2 - 6 } & $\begin{array}{c}\text { Shoot } \\
\text { height }\end{array}$ & $\begin{array}{c}\text { Water } \\
\text { content }\end{array}$ & $\begin{array}{c}\text { Dry shoot mass } \\
\text { production }\end{array}$ & $\begin{array}{c}\text { Fresh shoot mass } \\
\text { production }\end{array}$ & $\begin{array}{c}\text { Tolerance index } \\
\text { for dry shoot } \\
\text { mass production }\end{array}$ \\
\hline Covariate & $4.910^{*}$ & $4.133^{*}$ & 0.102 & 2.038 & $4.856^{*}$ \\
\hline Genotype (A) & $6.666^{* *}$ & $4.525^{* *}$ & $3.987^{* *}$ & $10.163^{* *}$ & 2.026 \\
\hline $\mathrm{c}\left(\mathrm{Pb}(\mathrm{NO})_{3}\right)$ (B) & $2.573^{*}$ & $2.853^{*}$ & $2.923^{*}$ & $2.859^{*}$ & 2.794 \\
\hline Interaction $\mathrm{A} \times \mathrm{B}$ & 0.816 & 1.138 & 0.361 & 0.269 & 0.504 \\
\hline
\end{tabular}

1) Labels for F-test: * - significant at the level $\alpha=0.05$; ** - significant at the level $\alpha=0.01$

\section{TABLE 7}

The effect of lead concentration in medium on the tolerance index for $\mathrm{Chl}$ a/b ratio in white poplar genotypes (LSD - test)

\begin{tabular}{|c|c|c|c|c|c|c|}
\hline $\mathrm{c}\left(\mathrm{Pb}\left(\mathrm{NO}_{3}\right)_{2}\right)(\mathrm{M})$ & Villafranca & L12 & L80 & LBM & $\begin{array}{c}\text { Mean value } \\
\text { by medium }\end{array}$ \\
\hline $10^{-6}$ & $1.373^{\mathrm{ab}}$ & $0.977^{\mathrm{cde}}$ & $1.159^{\mathrm{bc}}$ & $1.065^{\mathrm{cd}}$ & $0.708^{\mathrm{f}}$ & $1.068^{\mathrm{a}}$ \\
\hline $10^{-5}$ & $1.039^{\mathrm{cde}}$ & $0.940^{\text {cdef }}$ & $1.107^{\mathrm{c}}$ & $0.952^{\text {cdef }}$ & $1.073^{\mathrm{cd}}$ & $1.032^{\mathrm{ab}}$ \\
\hline $10^{-4}$ & $1.448^{\mathrm{a}}$ & $0.941^{\text {cdef }}$ & $1.013^{\mathrm{cde}}$ & $0.950^{\text {cdef }}$ & $0.836^{\text {def }}$ & $1.038^{\mathrm{ab}}$ \\
\hline $10^{-3}$ & $1.053^{\mathrm{cd}}$ & $0.958^{\mathrm{cde}}$ & $1.020^{\text {cde }}$ & $0.940^{\text {cdef }}$ & $0.801^{\text {ef }}$ & $0.954^{\mathrm{b}}$ \\
\hline Mean value by genotype & $1.228^{\mathrm{a}}$ & $0.954^{\mathrm{c}}$ & $1.089^{\mathrm{b}}$ & $0.976^{\mathrm{bc}}$ & $0.855^{\mathrm{c}}$ & \\
\hline
\end{tabular}

*) The differences among values marked with the same letter are not significant at the level $\alpha=0.05$ 


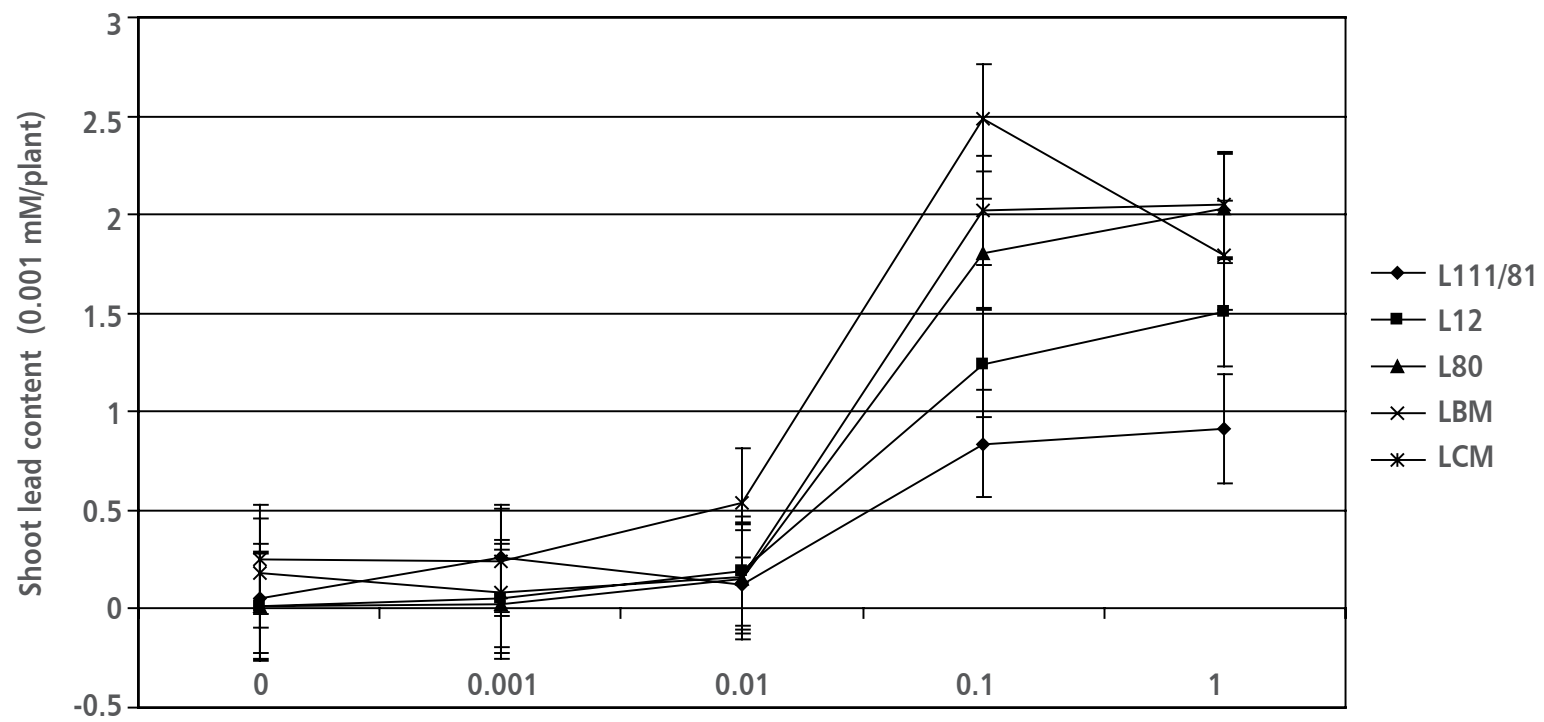

Lead concentration in medium (mM)

\section{FIGURE 1}

Shoot lead content ( $\mu \mathrm{M} \mathrm{Pb^{2+ } / p l a n t ) ~ i n ~ w h i t e ~ p o p l a r ~ p l a n t l e t s ~ g r o w n ~ o n ~ e x a m i n e d ~ g r o w i n g ~ m e d i a ~ ( S E ~ d e r i v e d ~}$ from the results of ANOVA is marked)

\section{Shoot Lead Accumulation and Content}

In contrast to other traits, the variation of shoot lead content per plant and variation of lead content in dry shoot mass (shoot lead accumulation) were influenced principally by the lead concentration in the media. ANOVA showed that influence to be highly significant (Table 2).

The shoot lead accumulation on the media with $10^{-4}$ and $10^{-3} \mathrm{M} \mathrm{Pb}\left(\mathrm{NO}_{3}\right)_{2}$ was significantly higher than on the media with other examined lead concentrations. The best differentiation in shoot lead accumulation among the examined genotypes was achieved with the concentration of $10^{-4} \mathrm{M} \mathrm{Pb}\left(\mathrm{NO}_{3}\right)_{2}$. The highest shoot lead accumulation on that medium was observed in genotype LCM, and the lowest in genotype "Villafranca" (Table 8).
The shoot lead content per plant data was associated with the results of shoot lead accumulation. A considerable increase in shoot lead content was observed on the media with $10^{-4}$ and $10^{-3} \mathrm{M} \mathrm{Pb}\left(\mathrm{NO}_{3}\right)_{2}$. The shoot lead content in "Villafranca" plants on $10^{-4}$ $\mathrm{M} \mathrm{Pb}\left(\mathrm{NO}_{3}\right)_{2}$ was more than 2.5 times lower than in LBM and LCM on the same medium (Figure 1).

\section{DISCUSSION}

The success of phytoextraction is mainly related to the ability of plants to tolerate the presence of a pollutant in the substrate and to accumulate it in their above-ground parts [14, 28]. Thus, high lead tolerance and accumulation were principal criteria in the evaluation of the genotypes in our research. Also, beside the selection of genotypes, the concentration

\section{TABLE 8}

The lead content in dry shoot biomass $(\mathrm{mg} / \mathrm{kg}$ ) (shoot lead accumulation) in white poplar rooted shoots grown on examined growing media (LSD - test)

\begin{tabular}{|c|c|c|c|c|c|c|}
\hline $\mathrm{c}\left(\mathrm{Pb}\left(\mathrm{NO}_{3}\right)_{2}\right)$ & Villafranca & L12 & L80 & LBM & LCM & $\begin{array}{c}\text { Mean value by } \\
\text { medium }\end{array}$ \\
\hline 0 & $5.123^{\left.e^{*}\right)}$ & $0.734^{\mathrm{e}}$ & $1.025^{\mathrm{e}}$ & $13.616^{\mathrm{e}}$ & $16.778^{\mathrm{e}}$ & $7.015^{b}$ \\
\hline $10^{-6}$ & 28.178 de & $2.728^{e}$ & $1.325^{\mathrm{e}}$ & $5.598^{e}$ & $14.316^{e}$ & $10.429^{b}$ \\
\hline $10^{-5}$ & $15.797^{e}$ & $17.767^{\mathrm{e}}$ & $11.670^{\mathrm{e}}$ & $16.651^{\mathrm{e}}$ & 37.856 de & $19.948^{b}$ \\
\hline $10^{-4}$ & $108.372^{c}$ & $117.031^{b c}$ & $121.150^{b c}$ & $174.934^{a b}$ & $186.062^{a}$ & $141.510^{\mathrm{a}}$ \\
\hline $10^{-3}$ & $87.390^{c d}$ & $111.331^{c}$ & $125.571^{a b c}$ & $135.521^{a b c}$ & $140.425^{a b c}$ & $120.047^{a}$ \\
\hline
\end{tabular}

$\left.{ }^{*}\right)$ The differences among values marked with the same letter are not significant at the level $\alpha=0.05$ 
of lead in the medium was evaluated in order to select the media that achieved the best differentiation among the genotypes, in order to determine the appropriate lead concentration for further in vitro tests.

Considering the tolerance of the examined genotypes, it may be said that there was no necrosis or decay of shoots on any media with lead, which indicates no significant lead pollution in the examined concentrations. This is consistent with the results obtained by Katanić et al. [21], who found no difference in leaf colour of white poplar shoots on the multiplication media with $0,10^{-5}$ and $10^{-4}$ $\mathrm{Pb}$.EDTA. However, in our experiment, root necrosis was present on the medium with $10^{-3} \mathrm{M} \mathrm{Pb}\left(\mathrm{NO}_{3}\right)_{2}$. This is in accordance with the results of Di Lonardo et al. [14], who found roots of white poplar genotypes in vitro to be more sensitive to heavy metals than shoots. The absence of a significant decrease of the content of photosynthetic pigments also confirmed that the examined lead concentrations had not severe inhibitory effects on the plants' vitality.

The tolerance indices based on morphological, biomass and photosynthetic pigment content traits also suggested a high tolerance of the examined genotypes on the applied lead concentrations.

Lead treatment had a stimulative effect on the number of roots. According to Seregin and Ivanov [7], low lead concentrations promoted root growth. However, on relatively high concentrations of 2.0 $\mathrm{mM} \mathrm{Pb}\left(\mathrm{NO}_{3}\right)_{2}$, Bojarczuk [20] found an inhibitory effect of on shoot and root development on the calluses of hybrid aspen on the regeneration medium. However, there were no significant differences among the genotypes in the tolerance indices based on the number of roots, as well as the length of the longest root (data not shown).

The tolerance index for shoot height (mostly above 1), indicated the absence of inhibition, if not a stimulative effect of the examined lead concentrations on shoot growth, especially in the medium with the $10^{-6} \mathrm{M} \mathrm{Pb}\left(\mathrm{NO}_{3}\right)_{2}$. The strong influence of differences among the genotypes recommeded this index to be used in tolerance evaluation tests in the future. According to the analysis of the covariance, shoot height was significantly influenced by the number of roots that also significantly influenced the shoot water content. The number of roots had no significant effect on dry shoot mass production, while the tolerance index based on shoot height significantly influenced the tolerance index of dry shoot mass production. These results suggested that the tolerance index based on shoot height is a good indicator of the lead tolerance of the tested genotypes. The positive effect of the implementation of this index would also be the option to establish more efficient and larger lead tolerance tests for white poplar genotypes in vitro. As the tolerance index for shoot height provided the best differentiation among the genotypes on the media with $10^{-4} \mathrm{M} \mathrm{Pb}\left(\mathrm{NO}_{3}\right)_{2}$, this lead concentration may be recommended in further testing.

The decrease in dry shoot mass production was observed on lead concentrations higher than $10^{-6} \mathrm{M}$ $\mathrm{Pb}\left(\mathrm{NO}_{3}\right)_{2}$. Kališova-Šprirochova et al. [19] reported a stimulative effect of $10^{-4} \mathrm{M} \mathrm{Pb}^{2+}$ on the total plant biomass accumulation in aspen rooted shoots in the liquid medium in vitro. However, Katanić et al. [21] found inhibitory effects on the fresh biomass of white poplar shoot tips grown on the multiplication medium supplemented with $10^{-4} \mathrm{M} \mathrm{Pb}$.EDTA. The differentiation among the genotypes in the tolerance index based on dry shoot biomass production was low. Significant differences were recorded only on $10^{-6} \mathrm{M} \mathrm{Pb}\left(\mathrm{NO}_{3}\right)_{2}$ where the genotype L-12 had a significantly higher index than in the standard genotype "Villafranca".

There was a low effect of lead concentration on the variation of photosynthetic pigment traits, except for the $\mathrm{Chl} \mathrm{a/b}$ ratio, where the influence of the interaction genotype $\times$ medium on its variation was significant. Ewais [29] found a statistically significant decrease of the content of photosynthetic pigments in leaves of three weed species grown in pots with $200 \mathrm{mg} /$ $\mathrm{kg}(0.6 \mathrm{mM} / \mathrm{kg})$ of $\mathrm{Pb}$ acetate. Also, Zengin and Munzuroglu [8] found a significant decrease on the chlorophyll content in leaves (about 10\%) together with the increase of several oxidative stress indicators in the lead-treated seedlings of common bean. However, Sarvari et al. [30] found a mild increase of the chlorophyll content in hydroponically grown white poplars in the nutrient solution with $10^{-5} \mathrm{M}$ $\mathrm{Pb}\left(\mathrm{NO}_{3}\right)_{2}$ and $10^{-4} \mathrm{M} \mathrm{Pb}\left(\mathrm{NO}_{3}\right)_{2}$, while $10^{-4} \mathrm{M} \mathrm{Pb}\left(\mathrm{NO}_{3}\right)_{2}$ had an inhibitory effect on the chlorophyll content in cucumber plants. Kalsila et al. [31] also found a slightly stimulative effect of lead acetate added to the substrate in the concentration $200 \mathrm{mg} / \mathrm{kg}$ of lead on the chlorophyll content in oat and barley leaves. In general, the tolerance index for $\mathrm{Chl}$ a/b ratio was higher than 1 at the low lead concentration $\left(10^{-6} \mathrm{M}\right.$ $\left.\mathrm{Pb}\left(\mathrm{NO}_{3}\right)_{2}\right)$, but decreased at higher concentrations. According to Sarvari et al. [30] the increase of Chl $\mathrm{a} / \mathrm{b}$ ratio in poplar leaves in hydroponics with 10 $\mu \mathrm{M} \mathrm{Pb}^{2+}$ may be explained by the increase in the amount of core complexes. However, at a higher lead concentration $(100 \mu \mathrm{M})$, the lowering of the $\mathrm{Chl} \mathrm{a} / \mathrm{b}$ ratio occured due to a stronger decrease in the amount of PSI and the relative stability of PSII. Kamel [32] found a higher $\mathrm{Chl}$ a/b ratio on $4.8 \mathrm{mM} \mathrm{Pb}^{2+}$ and lower in the $48 \mathrm{mM} \mathrm{Pb}^{2+}$ solution 
compared to the control in Vicia faba hydroponics after 96 hours of growth. The best differentiation among the examined genotypes, according to the tolerance index based on the $\mathrm{Chl} a / b$ ratio, was observed on media with $10^{-4}$ and $10^{-3} \mathrm{M} \mathrm{Pb}\left(\mathrm{NO}_{3}\right)_{2}$. Regarding the results of Sarvari et al. [30], high values for "Villafranca" indicated a lower disturbance in chlorophyll synthesis and thus a higher lead tolerance by this parameter. However, the changes in tolerance indices based on the $\mathrm{Chl}$ a or $\mathrm{Chl} \mathrm{b}$ content in shoot fresh mass may not be detected (data not shown), which additionally supported the conclusion of low differences among the examined genotypes in their lead tolerance.

The highest shoot lead accumulation and shoot lead content of the examined white poplar genotypes appeared on the media with $10^{-4}$ and $10^{-3} \mathrm{M} \mathrm{Pb}\left(\mathrm{NO}_{3}\right)_{2}$. The best differentiation among the genotypes was achieved on the $10^{-4} \mathrm{M} \mathrm{Pb}\left(\mathrm{NO}_{3}\right)_{2}$ medium. This is consistent with Sakan et al. [9] who found that shoot lead accumulation in the leaves of white poplar plants was not significant in hydroponics with $10^{-5}$ $\mathrm{M} \mathrm{Pb}\left(\mathrm{NO}_{3}\right)_{2}$, but it was in hydroponics with $10^{-4} \mathrm{M}$ $\mathrm{Pb}\left(\mathrm{NO}_{3}\right)_{2}$. These results suggested that the medium with $10^{-4} \mathrm{M} \mathrm{Pb}\left(\mathrm{NO}_{3}\right)_{2}$ may be recommended to be applied in further tests on shoot lead accumulation in white poplar tissue cultures.

The widely-used genotype "Villafranca" was used as the standard $[14,18]$ in evaluation of the genotype tolerance to different lead concentrations, as well as the shoot lead accumulation. Lead tolerance was satisfying in the examined genotypes but the differences among them were rather low, in general. The mostly used tolerance indices in lead tolerance studies are based on the length of the longest root [33] or dry mass production [14], but in our research they gave a poor differentiation among the genotypes. The best differentiation was obtained by the tolerance index based on shoot height. According to this parameter, the most tolerant were genotypes $L-80$ and $L-12$. On the other hand, lead accumulation in the aboveground parts appeared to be highly influenced by the differences among the genotypes, emphasizing the importance of shootlead accumulation in the evaluation of the genotypes for the lead phytoextraction potential. The highest shoot lead accumulation on the medium with $10^{-4} \mathrm{M} \mathrm{Pb}\left(\mathrm{NO}_{3}\right)_{2}$ was achieved by the genotype LCM (cca. 70\% higher compared to "Villafranca"). The relation among the genotypes was similar for shoot lead content, but the difference between LCM and "Villafranca" was observed to be even higher (almost 200\%). Beside LCM, similar results were observed also in the genotype LBM. Thus, as the tolerance of genotypes LCM and LBM was at the same level as most of the other genotypes and they achieved a high shoot lead accumulation, they may be recommended for further examination in lead phytoextraction plantations.

Considering the observed differences among the examined genotypes regarding lead tolerance and accumulation, in vitro tests may be utilized for selecting a group of candidate genotypes for lead phytoextraction projects. Watson et al. [34] and Pulford et al. [35] demonstrated in Salix sp. that the results obtained in hydroponics and in field are comparable. The general opinion is that the differences in the bioavailability of contaminants, the processes of pollutant uptake and metabolite distribution are likely to be substantial in tissue culture and field conditions. Thus, based on the results from tissue cultures, the response of plants to environmental contaminants may be predicted with a cost reduction of the subsequent conventional whole plant experiments $[36,37]$. However, for the final evaluation of a particular genotype, further research should be done considering the lower availability of lead in soil, the higher juvenility of the in vitro material and the complexity of interactions between plants and their habitat.

\section{CONCLUSIONS}

According to the presented results, the following conclusions were drawn for the examined group of white poplar genotypes:

The tested lead concentrations had a positive effect on a number of formed roots, and by this trait on further on shoot moisture content and shoot height.

The tolerance index based on shoot height (significantly related to the tolerance index based on dry shoot mass production) and lead shoot content on a medium with $10^{-4} \mathrm{M} \mathrm{Pb}\left(\mathrm{NO}_{3}\right)_{2}$ were proposed to be used in further lead tolerance and accumulation research and testing.

Two examined genotypes of horticultural value (LCM and LBM) achieved a significantly higher lead shoot content compared to the wide-spread genotype "Villafranca" (almost 200\% and 125\% higher, respectively).

\section{Acknowledgements}

This paper was realized as a part of the project "Studying Climate Change and its Influence on the Environment: Impacts, Adaptation and Mitigation" (43007), financed by the Ministry of Education and Science of the Republic of Serbia within the framework of the integrated and interdisciplinary research for the period between 2011-2014. 


\section{REFERENCES}

1. ARORA M, KIRAN B, RANI S, RANI A, KAUR B, MITTAL N 2008 Heavy metal accumulation in vegetables irrigated with water from different sources. Food Chem 111 (4): $811-815$

2. VAN ASSCHE F, CLIJSTERS H 1990 Effects of metals on enzyme activity in plants. Plant Cell Environ 13 (3): 195206

3. BURZYŃSKI M, BUCZEK J 1998 Uptake and assimilation of ammonium ions by cucumber seedlings from solutions with different $\mathrm{pH}$ and addition of heavy metals. Acta Soc Bot Pol 76 (2): 197-200

4. OLEKSYN J, KAROLEWSKI P, GIERTYCH M J, WERNER A, TJOELKER M G, REICH P B 1996 Altered root growth and plant chemistry of Pinus sylvestris seedlings subjected to aluminium in nutrient solution. Trees 10 (3): 135-144

5. ZHANG Y 2003100 Years of Pb deposition and transport in soils in Champaign, Illinois, U.S.A. Water Air Soil Pollut $146(1-4): 197-210$

6. SHARMA P, DUBEY RS 2005 Lead toxicity in plants. Braz J Plant Physiol 17 (1): 35-52

7. SEREGIN I V, IVANOV V B 2001 Physiological aspects of cadmium and lead toxic effects on higher plants. Russ $J$ Plant Physl+ 48 (4): 523-544

8. ZENGIN FK, MUNZUROGLU O 2005 Effects of some heavy metals on content of chlorophyll, proline and some antioxidant chemicals in bean (Phaseolus vulgaris L.) seedlings. Acta Biol Cracov Bot 47/2: 157-164

9. SAKAN S M, ĐOREVIĆ D S, MANOJLOVIĆ D D, POLIĆ P S 2009 Assessment of heavy metal pollutants accumulation in the Tisza river sediments. J Environ Manage 90 (11): 3382-3390

10. PIVETZ B E 2001 Ground water issue: Phytoremediation of contaminated soil and ground water at hazardous waste sites. U.S. Environmental Protection Agency, Technology Innovation Office, Office of Solid Waste and Emergency Response, Washington, DC, p 36

11. BARCELO J, POSCHENRIEDER C 2003 Phytoremediation: principles and perspectives. Contrib Sci 2 (3): 333-344

12. GHOSH M, SINGH SP 2005 A review on phytoremediation of heavy metals and utilization of its byproducts. App Ecol Env Res 3 (1): 1-18

13. PULFORD I D, WATSON C 2003 Phytoremediation of heavy metal-contaminated land by trees - a review. Environ Int 29 (4): 529-540

14. DI LONARDO S, CAPUANA M, ARNETOLI M, GABBRIELLI R, GONNELLI C 2011 Exploring the metal phytoremediation potential of three Populus alba L. clones using an in vitro screening. Environ Sci Pollut $R 18$ (1): 82-90

15. AITCHISON E W, KELLEY S L, ALVAREZ P J J, SCHOOR J L 2000 Phytoremediation of 1,4-dioxane by hybrid poplar trees. Water Environ Res 72 (3): 313-321

16. EGGENS C F, LOUGHEED E C, HILTON R J 1972 Rooting of hardwood cuttings of boleana poplar. Can J Plant Sci 52: 599-604
17. KOVACEVIC B, ORLOVIC S, RONCEVIC S, MILADINOVIC D 2010 The effect of silver ion, 1-napthalene acetic acid and 6-benzylaminopurine on micropropagation of "Fastgiate" tree shape variety Populus alba cl. LBM. Acta Hort 885: 197-202

18. CASTIGLIONE S, FRANCHIN C, FOSSATI T, LINGUA G, TORRIGIANI P, BIONDI S 2007 High zinc concentrations reduce rooting capacity and alter metallothionein gene expression in white poplar (Populus alba L. cv. Villafranca). Chemosphere 67 (6): 1117-1126

19. KALIŠOVA-ŠPIROCHOVA I, PUNČOCHAROVA J, KAFKA Z, KUBAL M, SOUDEK P, VANEK T 2003 Accumulation of heavy metals by in vitro cultures of plants. Water Air Soil Pollut 3 (3): 269-276

20. BOJARCZUK K 2004 Effect of toxic metals on the development of poplar (Populus tremula L. x $P$. alba L.) cultured in vitro. Pol J Environ Stud 13 (2): 115-120

21. KATANIC M, PILIPOVIC A, ORLOVIC S, KRSTIC B 2007 The influence of lead on the shoot growth and concentration of photosynthetic pigments in leaves of the white poplar Populus alba clones in vitro. Topola (Poplar) 179-180: 1524 (in Serbian with English summary)

22. KATANIC M, PILIPOVIC A, ORLOVIC S, KRSTIC B, KOVACEVIC B, PEKEC S 2008 The influence of nickel, cadmium and lead on the growth of the white poplar clones' shoots in vitro. In: Orlović S (ed) Proceedings of International scientific conference "Forestry in achieving millennium goals", 13-15 November 2008, Novi Sad, Serbia, pp 443-446

23. BITTSANSZKY A, KOMIVES T, GULLNER G, GYULAI G, KISS J, HESZKY L, RADIMSZKY L, RENNENBERG H 2005 Ability of transgenic poplars with elevated glutathione content to tolerate zinc ${ }^{2+}$ stress. Environment International 31 (2): 251-254

24. AHUJA M R 1984 A commercially feasible micropropagation method for aspen. Silvae Genet 32 (4-5): 174-176

25. WETTSTEIN D 1957 Chlorophyll-letale und der submikroskopische formwechsel der plastiden. Exp Cell Res 12 (3): 427-506

26. TURNER R C, MARSHAL C 1972 The accumulation of zinc by subcellular fractions of roots of Agrostis tenuis Sibth. in relation to zinc tolerance. New Phytol 71 (4): 671-676

27. STATSOFT INC. 2011 STATISTICA (data analysis software system), version 10

28. HUANG J W, CHEN J, BERTI W R, CUNNINGHAM S D 1997 Phytoremediation of lead-contaminated soils: Role of synthetic chelates in lead phytoextraction. Environ Sci Technol 31 (3): 800-805

29. EWAIS E A 1997 Effects of cadmium, nickel and lead on growth, chlorophyll content and proteins of weed. Biol plantarum 39 (3): 403-410

30. SARVARI E, GASPAR L, FODOR F, CSEH E, KROEPFL K, VARGA A, BARON M 2002 Comparison of the effect of $\mathrm{Pb}$ treatment on thylacoid development in poplar and cucumber plant. Acta Biol Szeged 46 (3-4): 163-165 
31. KAZNINA N M, LAIDINEN G F, TITOV A F, TALANOV A V 2005 Effect of lead on the photosynthetic apparatus of annual grasses. Biol Bull 32 (2): 147-150

32. KAMEL H A 2008 Lead accumulation and its effect on photosynthesis and free amino acids in Vicia faba grown hydroponically. Aust J Basic App/ Sci 2 (3): 438-446

33. MICHALAK E, WIERZBICKA M 1998 Differences in lead tolerance between Allium cepa plants developing from seeds and bulbs. Plant Soil 199 (2): 251-260

34. WATSON C, PULFORD I D, RIDDELL-BLACK D 2003 Screening of willow species for resistance to heavy metals:
Comparison of performance in a hydroponics system and field trials. Int J Phytoremediat 5 (4): 351-365

35. PULFORD I D, RIDDELL-BLACK D, STEWART C 2002 Heavy metal uptake by willow clones from sewage sludgetreated soil: the potential for phytoremediation. Int $J$ Phytoremediat 4 (1): 59-72

36. DORAN P M 2009 Application of plant tissue cultures in phytoremediation research: Incentives and limitations. Biotechnol Bioeng 103 (1): 60-76

37. CAPUANA M 2011 Heavy metals and woody plants biotechnologies for phytoremediation. iForest 4: 7-15 